\title{
L-428 Nodular Sclerosing Hodgkin's Cell Secretes a Unique Transforming Growth Factor-beta Active at Physiologic pH
}

Samuel R. Newcom, ${ }^{*}$ Marshall E. Kadin, ${ }^{\star}$ Aftab A. Ansari, ${ }^{\mathbf{5}}$ and Volker DiehI"

Departments of ${ }^{*}$ Medicine and ${ }^{\S}$ Pathology, Emory University, Atlanta, Georgia 30322; ${ }^{\ddagger}$ Department of Pathology, Harvard University Medical School, Boston, Massachusetts 02215; and the "First Medical Department, University of Cologne, Federal Republic of Germany

\begin{abstract}
Nodular sclerosing Hodgkin's disease is characterized by dense collagen fibrosis. Although transforming growth factorbeta (TGF- $\beta$ ) is an important bifunctional growth factor for fibroblasts and is stored and released by many cells, it requires acidification to $\mathrm{pH}$ 2.0-3.0 before it becomes a biologically active growth factor. We show here that the L-428 Hodgkin's cell releases a high molecular weight TGF that competes for the TGF- $\beta$ cell membrane receptor but not the TGF- $\alpha$ receptor. This growth factor is most active at physiologic $\mathrm{pH}$ and is 97\% inactivated by acidification. Hodgkin's TGF is also inactivated by proteases and can be preserved by protease inhibitors. The Hodgkin's TGF can be separated from an autocrine growth factor using either column chromatography or electroelution from gels and is shown to have a molecular weight of $\sim$ 350,000. Incubation of the Hodgkin's TGF in SDS releases a 25,000-D protein with reduced biological activity but which cross-reacts with anti-TGF- $\beta$ IgG. We propose that L-428 nodular sclerosing Hodgkin's disease fibrosis is mediated by a potent high molecular weight TGF- $\beta$ which, unlike TGF- $\beta$ characterized to date, is secreted in a form most active at physiologic pH.
\end{abstract}

\section{Introduction}

Nodular sclerosing Hodgkin's disease is the most common pathological subtype of Hodgkin's disease and is characterized by dense collagen bands which, in addition to benign cellular proliferation, account for the bulk of the Hodgkin's neoplasm $(1,2)$. Attempts to demonstrate malignant properties of the fibroblasts within the sclerosis have proven futile (3) and have led to the hypothesis that the fibroblast proliferation is secondary to diffusible growth factors secreted by adjacent cells, perhaps the malignant Reed-Sternberg cells $(3,4)$.

We have previously shown that short-term, partially purified Reed-Sternberg cell cultures secrete a potent growth factor for fibroblasts into the serum-free medium (3), that the growth factor is secreted in an active form at physiologic $\mathrm{pH}$, that the growth factor does not have the biological properties of IL 1 (4), and that it produces transformation-like growth of fibroblasts in monolayer and soft agar $(3,4)$. To determine the

Address reprint requests to Dr. Samuel R. Newcom, Emory University School of Medicine, 46 Armstrong, S. E., Atlanta, GA 30303. 1988.

Received for publication 4 January 1988 and in revised form 1 July

J. Clin. Invest.

(c) The American Society for Clinical Investigation, Inc.

0021-9738/88/12/1915/07 \$2.00

Volume 82, December 1988, 1915-1921 identity of the growth factor we have studied a cell culture, L-428, established from the pleural effusion of a woman with refractory stage IV B nodular sclerosing Hodgkin's disease (5, 6). L-428 Hodgkin's cells resemble fresh uncultured Hodgkin's cells in most aspects studied including surface antigen phenotype, morphology, cytochemistry, and gene rearrangement (5-8). Therefore, we propose that observations made of L-428 Hodgkin's cells in vitro may be useful in understanding the pathophysiology of nodular sclerosing Hodgkin's disease.

The transforming growth factor (TGF) ${ }^{1}$ produced by $\mathrm{L}-428$ cells is characterized in this report. This growth factor, although binding to the TGF- $\beta$ receptor and sharing many biological features of TGF- $\beta$, is unlike TGF- $\beta$ because it is secreted in an active high molecular weight form. This observation is important, not only because of its relevance to nodular sclerosing Hodgkin's disease, but because it demonstrates that TGF- $\beta$ can be secreted in a form that is active at physiologic $\mathrm{pH}$ and is more potent than the tissue extracts and cell products reported to date (9-20). As well as being an important growth factor in Hodgkin's disease, it is suggested that this form of TGF- $\beta$ should be investigated as a possible mediator of benign cell growth in conditions other than Hodgkin's disease.

\section{Methods}

\section{Growth factors}

Receptor-grade epidermal growth factor (EGF) and ${ }^{125}$ I-EGF were from Collaborative Research, Inc., Lexington, MA. TGF- $\beta 1$ was from R \& D Systems, Inc. (Minneapolis, MN). This porcine platelet TGF- $\beta$ preparation has been demonstrated to be homogeneous by analysis on SDS-polyacrylamide gels and identical to human TGF- $\beta$ in bioassay, receptor binding, and amino acid sequence (9). ${ }^{125}$ I-TGF- $\beta$ was a kind gift from the Laboratory of Chemoprevention, National Institutes of Health (Dr. Michael B. Sporn, Chief).

\section{Hodgkin's cells}

L-428 nodular sclerosing Hodgkin's cells were maintained in T-150 flasks or roller bottles $\left(850 \mathrm{~cm}^{2}\right)$ in Iscove's medium supplemented with $5 \mu \mathrm{g} / \mathrm{ml}$ insulin, $5 \mu \mathrm{g} / \mathrm{ml}$ transferrin, $5 \mathrm{ng} / \mathrm{ml}$ selenium, $2 \mathrm{mM}$ L-glutamine, $1 \%$ penicillin-streptomycin, and $4 \%$ FCS. All cultures were in double-jacketed incubators with $7.5 \% \mathrm{CO}_{2}$ and maximum humidity. Cells were fed twice weekly and maintained at a concentration of $1-5 \times 10^{6}$ cells $/ \mathrm{ml}$. The doubling time was 48-72 h. EBV nuclear antigen was excluded by staining. Mycoplasma was excluded using Hoechst staining, cultures of spent media, and transmission electron microscopy. Positive staining of L-428 cells for HLA-DR, $\mathrm{Ki}-1$, Leu M-1, and T-9 was demonstrated by immunoperoxidase ( 21 , 22). Cytogenetics confirmed the cells were of human female origin. Frozen samples of the cells were maintained in $8 \%$ dimethylsulfoxide in fetal calf serum at $-196^{\circ} \mathrm{C}$. Viabilities of thawed cells were routinely $>80 \%$ by trypan blue dye exclusion. 
Preparation of serum-free conditioned medium (CM) from L-428 cells

L-428 Hodgkin's cells were seeded into roller bottles in $200 \mathrm{ml}$ of supplemented Iscove's medium at a concentration of $1 \times 10^{5} \mathrm{cells} / \mathrm{ml}$. For serum-free incubation, the cells were washed two times and eluted two times ( $30 \mathrm{~min}$ and $18 \mathrm{~h}$ ) to allow elution of all bound proteins. The elution washes were discarded. A 72-h incubation in $250 \mathrm{ml}$ of serumfree Iscove's medium $\left(1 \times 10^{6} \mathrm{cells} / \mathrm{ml}\right)$ was used to collect the secreted Hodgkin's TGF. The CM was remoyed, clarified by centrifugation at $1,200 \mathrm{~g}$ for $20 \mathrm{~min}$, and filtered through a $0.2-\mu \mathrm{m}$ filter. Portions of the CM were concentrated $50-100$ times (500 $\mathrm{ng}$ protein $/ \mathrm{ml}$ ) using a stir cell (Amicon Corp., Danvers, MA) with a 1,000-D cut-off (YM2). Serum-free $C M$ was dialyzed against Iscove's medium before being tested for biological activity.

\section{Test cells}

Test cell lines included clone 49F normal rat kidney (NRK) cells (a kind gift from Dr. George Todaro, Oncogene, Seattle, WA), AKR-2B cells (a kind gift from Dr. Harold Moses, Vanderbilt University, Nashville, TN), NIH 3T3 cells, human skin fibroblasts, human embryonic pulmonary fibroblasts, human thymocytes, and mink lung epithelial cells (CCL 64). All cell types were routinely cultured in Iscove's medium supplemented with $10 \%$ calf serum, $2 \mathrm{mM}$ L-glutamine, $50 \mu \mathrm{g}$ gentamicin $/ \mathrm{ml}$, and $2.5 \mu \mathrm{g}$ fungizone $/ \mathrm{ml}$. Cell stocks were passaged every $7-10 \mathrm{~d}$ and maintained in $7.5 \% \mathrm{CO}_{2}$ incubators at $37^{\circ} \mathrm{C}$. Fibroblasts were used for bioassay in passages one to six and then discarded. Early passage cells were cryopreserved in $8 \%$ DMSO in FCS at $-196^{\circ} \mathrm{C}$. Thawed viabilities were routinely $>80 \%$ by trypan blue exclusion. Thymocytes were primary explants and epithelial cells were maintained in continuous culture.

\section{Cell growth measurements}

Monolayer fibroblast growth experiments were performed as previously described $(3,4)$. All cell counts were performed in triplicate by obtaining a single cell suspension in trypsin $(0.25 \%)$ and counting in an electronic cell counter (Coulter Electronics, Hialeah, FL). Sample 35-mm dishes were fixed in formalin $(10 \%)$ and stained with methylene blue for correlation. To measure DNA synthesis, NRK cells, L-428 cells, human thymocytes, or epithelial cells were prepared as a single cell suspension and studied as previously described (4). Cells were cultured for $24 \mathrm{~h}$ (NRK, L-428, and epithelial cells), or $72 \mathrm{~h}$ (thymocytes) in flat-bottomed microtiter dishes in the presence of control media or Hodgkin's TGF. $\left[{ }^{3} \mathrm{H}\right]$ Thymidine $(0.5 \mu \mathrm{Ci}$, New England Nuclear) was added for $16 \mathrm{~h}$ and the cells were collected on glass filters, dried, and counted in a scintillation counter.

\section{TGF- $\beta$ assays}

(a) Fibroblast colonies in soft agar. Crude or purified Hodgkin's TGF was measured for TGF- $\beta$ activity at three or more dilutions. The bioassay for TGF- $\beta$ depends upon the ability of TGF- $\beta$ to induce anchorage-independent growth of AKR-2B fibroblasts or NRK fibroblasts in soft agar. The agar assay was performed as previously described $(3,4)$ and a response curve constructed with each experiment using 10-12 dilutions of known concentrations of highly purified platelet TGF- $\beta$. This assay detects and quantitates TGF- $\beta$ in picomolar concentrations. A single cell suspension was documented after plating and colonies were counted after $14 \mathrm{~d}$ of incubation using an inverted microscope with phase optics.

(b) Radioreceptor assay. A competitive binding assay that uses AKR-2B TGF- $\beta$ cell membrane receptors was performed using ${ }^{125} \mathrm{I}$ TGF- $\beta$. As measured in our laboratory, each AKR-2B cell has $\sim 13,000$ receptors for TGF- $\beta$. These receptors appear to be of two classes, by analysis with ${ }^{125}$ I-TGF- $\beta$ binding. 4,500 receptors/cell have a $K_{\mathrm{d}}$ of $1.5 \mathrm{pM}$ and 8,500 receptors/cell have a $K_{\mathrm{d}}$ of $13.6 \mathrm{pM}$. To test Hodgkin's TGF for TGF- $\beta$ receptor binding, AKR-2B cells ( 5 $\times 10^{5} / 35-\mathrm{mm}$ dish) were incubated for $2 \mathrm{~h}$ in known concentrations of TGF- $\beta$ and in dilutions of high molecular weight Hodgkin's TGF at $25^{\circ} \mathrm{C}$ in $5 \% \mathrm{CO}_{2}$. After being washed twice, the cells were incubated with ${ }^{125}$ I-TGF- $\beta$ for $2 \mathrm{~h}$. After incubation the cells were washed four times with cold Hank's salt solution containing $0.1 \%$ BSA. The cells were solubilized with $0.6 \mathrm{ml}$ Triton solution ( $20 \mathrm{mM}$ Hepes, $2 \%$ Triton $\mathrm{X}-100,10 \%$ glycerol, $0.01 \% \mathrm{BSA}, \mathrm{pH} 7.4$ ) by a $5-10$-min incubation at room temperature and were counted using a gamma counter.

(c) Inhibition of epithelial cell DNA synthesis. CCL-64 cells are potently inhibited by TGF- $\beta$ in picomolar concentrations (18). DNA synthesis by CCL-64 cells in control medium was compared to DNA synthesis in 8-10 concentrations of TGF- $\beta$ or 3-5 concentrations of Hodgkin's TGF.

\section{Biochemical characterization}

(a) pH sensitivity of Hodgkin's TGF. Purified Hodgkin's TGF was rapidly exchanged into $1 \mathrm{M}$ acetic acid $(\mathrm{pH}=2.0)$ using either a stir cell with a YM2 filter or a Sephadex G 25 column (Pharmacia Fine Chemicals, Piscataway, NJ). Aliquots were then reequilibrated in Iscove's medium $(\mathrm{pH}=7.4)$ at $15,30,60$, and $120 \mathrm{~min}$ for TGF- $\beta$ measurement.

(b) Preservation of Hodgkin's TGF using protease inhibitors. Fresh CM from L-428 cells (serum-free) was prepared using protease inhibitors (5.3 mg\% PMSF and $0.3 \mathrm{mg} \%$ pepstatin $\mathrm{A}$ ) that were added at 1,6 , and $24 \mathrm{~h}$. After addition of the inhibitors, the $C M$ was dialyzed against serum-free Iscove's medium and tested for TGF- $\beta$ activity. This experiment assessed the potential role of endogenous proteases in the activation of Hodgkin's TGF.

(c) PAGE. Using a modification of the Laemmli method (23) Hodgkin's TGF was electrophoresed into 4-30\% gels. Biological activity was tested by slicing the gels horizontally and removing the growth factor by electroelution. Molecular weight determination of purified specimens from column chromatography and ion exchange was made using $1 \%$ SDS. Gels were fixed in methanol and stained with either Coomassie brilliant blue or silver. Western blotting was performed using nitrocellulose paper and an 18-h transfer at $60 \mathrm{~V}$. A polyclonal affinity-purified rabbit IgG anti-TGF- $\beta$ was used to bind Hodgkin's TGF- $\beta$ (R \& D Systems, Inc., Minneapolis, MN). Staining of bound antibody was performed using a biotinylated anti-rabbit affinity-purified antibody and alkaline phosphate-conjugated avidin.

(d) Column chromatography. Molecular sizing was performed using a $1.6 \times 100 \mathrm{~cm}$ column packed with a cross-linked agarose gel (Sepharose-CL6B). The linear fractionation range is 1,500-650,000 D. The column was equilibrated in a Tris-saline buffer ( $100 \mathrm{mM}$ Tris, 200 $\mathrm{mM} \mathrm{NaCl}, 2 \mathrm{mM}$ EDTA, pH 8.0). A selectivity curve was constructed using standard compounds of known molecular mass (thyroglobulin $670 \mathrm{kD}$, gamma globulin $160 \mathrm{kD}$, ovalbumin $44 \mathrm{kD}$, myoglobin 17 $\mathrm{kD}$, cyanocobalamin $1.35 \mathrm{kD}$ ). The protein concentration of each column fraction was estimated using an ultraviolet spectrophotometer $\left(\mathrm{OD}_{280}\right)$. Ion exchange was performed using $1 \times 10 \mathrm{~cm}$ columns packed with either carboxymethyl (CM)-agarose or DEAE-agarose. Elution was performed using a $\mathrm{KCl}$ gradient $(0-0.6 \mathrm{M})$ in a $50-\mathrm{mM}$ imidazole buffer, $\mathrm{pH}$ 7.0. The column was regenerated using $250 \mathrm{mM}$ imidazole.

Northern blots. Total RNA was isolated from L-428 Hodgkin's cells or control cells using a guanidine thiocyanate method. The purified total RNA was electrophoresed into agarose-formaldehyde gels and transferred to nylon membranes. The size-fractionated RNA was probed using a ${ }^{32} \mathrm{P}$-labeled Eco $\mathrm{R} 1$ insert from $\lambda \beta \mathrm{C} 1$ that recognized a mRNA of 2.5 kb (a kind gift from Dr. Ric Derynck, Genentech, So. San Francisco, CA [24]).

\section{Results}

\section{TGF activity}

Maximum NRK colony formation in soft agar with $5 \mathrm{ng} / \mathrm{ml}$ EGF was potentiated with Hodgkin's TGF indicating TGF- $\beta$ activity. A quantitative AKR-2B bioassay indicated production of concentrated aliquots of Hodgkin's TGF containing 40-100 pM TGF- $\beta$ activity. Purification by chromatography 


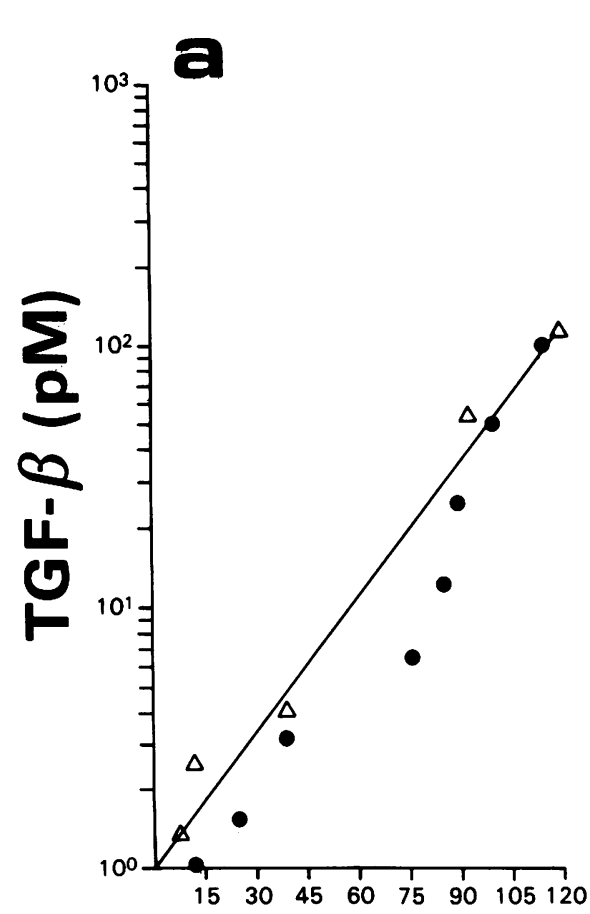

AKR-2B Colonies/35 mm Dish
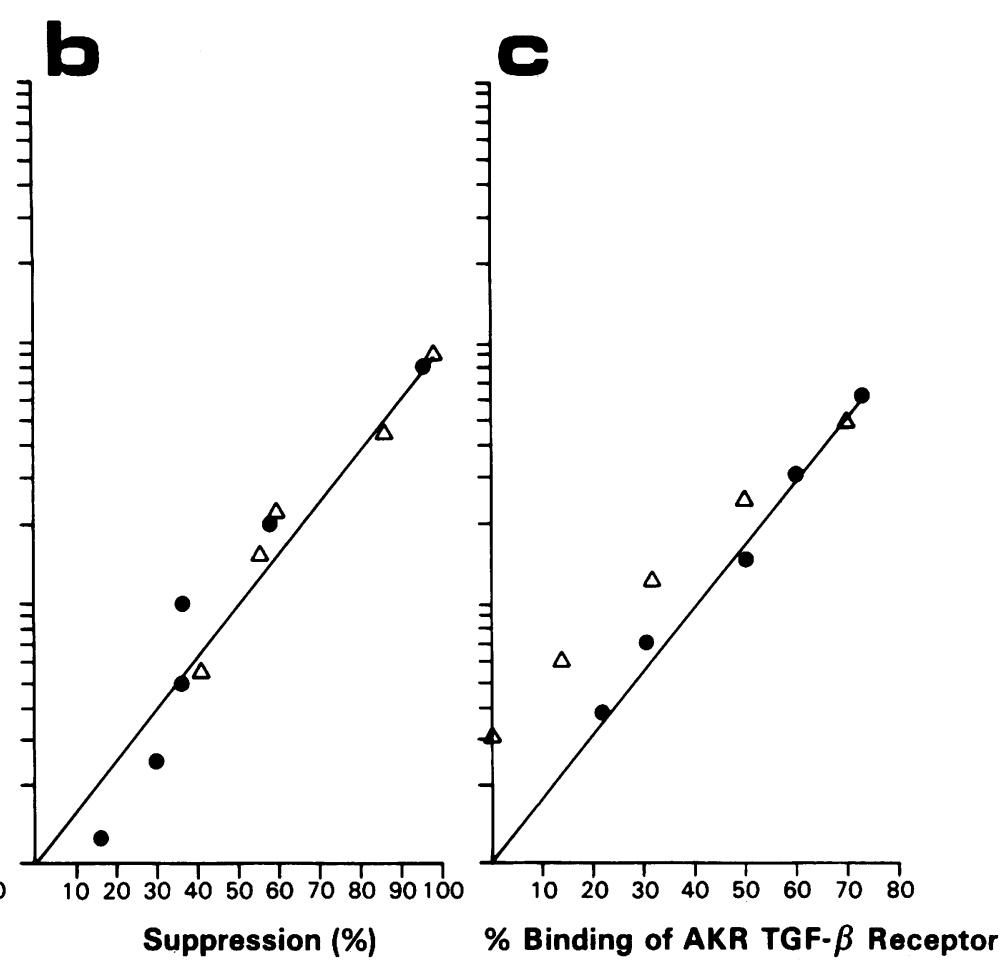

Figure 1. High molecular weight Hodgkin's TGF was purified using column chromatography followed by electroelution from gel slices. Biological activity of $(\Delta)$ Hodgkin's TGF was compared with TGF- $\beta 1$ from $(\bullet)$ platelets and is shown to have similar biological activities: $(A)$ AKR-2B colony formation in soft agar, $(B)$ inhibition of epithelial cell DNA synthesis, and $(C)$ competition for the TGF- $\beta$ cell membrane receptor.

and electroelution from gels at physiologic $\mathrm{pH}$ indicated all activity could be found in the high molecular weight fractions. A titration curve of purified Hodgkin's TGF is compared with platelet TGF- $\beta$ in Fig. $1 A$.

\section{Epithelial cell DNA synthesis inhibition}

Almost complete inhibition of epithelial cell DNA synthesis could be obtained with picomolar concentrations of platelet TGF- $\beta 1$ or high molecular weight Hodgkin's TGF. The titration curves of purified Hodgkin's TGF and platelet TGF- $\beta$ were parallel and overlapping (see Fig. $1 B$ ).

\section{Receptor binding}

The receptor binding assays indicated specific competition of Hodgkin's TGF for the AKR-2B cell TGF- $\beta$ receptor. Using this assay, each L-428 Hodgkin's cell was estimated to produce $1 \mathrm{fM}$ TGF- $\beta / \mathrm{d}$. A titration curve of purified high molecular weight Hodgkin's TGF receptor binding could be approximated to the binding curve obtained with platelet TGF- $\beta$ (see Fig. $1 C$ ). There was no evidence of competition for the TGF- $\alpha$ (EGF) receptor.

\section{Northern blots}

L-428 Hodgkin's cells, when shown to produce TGF- $\beta$ activity, were examined to determine if they expressed mRNA for TGF- $\beta$. Fig. 2 demonstrates expression of TGF- $\beta$ mRNA in L-428 Hodgkin's cells and compares the amount of expression with that obtained from three control lymphoid cell lines.

Fibroblast growth-measurements in monolayer culture

Fig. 3 compares the results of cell growth experiments using human embryonic fibroblasts, NRK fibroblasts, and 3T3 cells in control media and CM from L-428 Hodgkin's cells. There was significant potentiation of human fibroblast and 3T3 cell growth by the Hodgkin's TGF but inhibition of NRK cells. Human skin fibroblasts were also stimulated to divide by Hodgkin's TGF and, at confluence, achieved 1 doubling greater than control medium. These findings are identical to those observed with TGF from fresh Hodgkin's cells $(3,4)$.

\section{Effect of Hodgkin's TGF on NRK DNA synthesis}

To confirm the paradoxical inhibition of NRK cells in monolayer culture but stimulation of colony formation in soft agar

\section{TGF- $\beta$ MRNA IN LYMPHOMA CELL LINES}

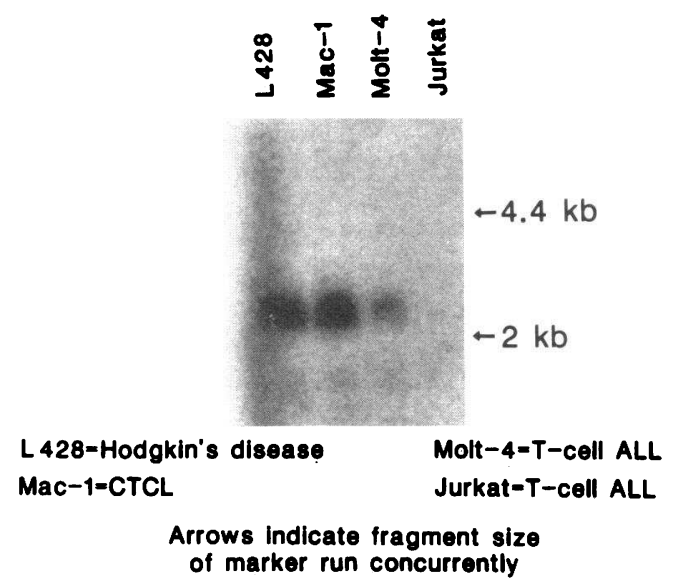

Figure 2. Demonstration of mRNA for TGF- $\beta$ in the L-428 Hodgkin's cell. Control cells, Mac-1, a cutaneous T-cell lymphoma (CTCL), and MOLT-4, also have significant mRNA for TGF- $\beta$. 


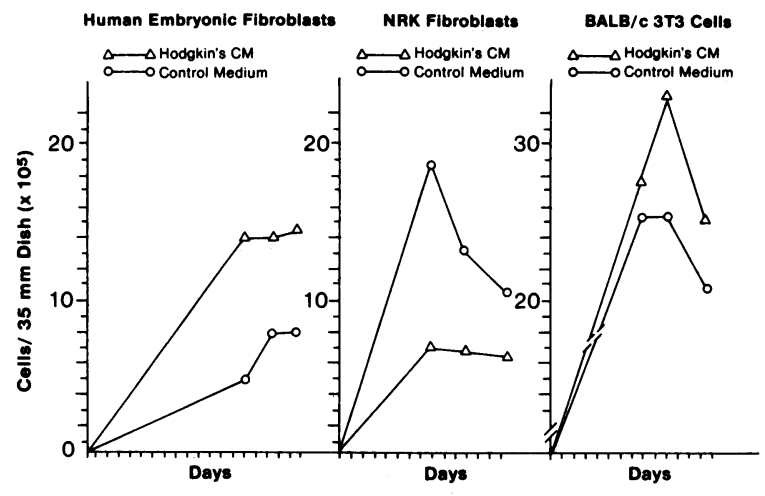

Figure 3. Monolayer cell proliferation of embryo fibroblasts in response to Hodgkin's TGF. Each value is the mean of triplicate dishes. The standard error of measurement is $<10 \%$ of the mean for each value.

we compared the effect of control medium and L-428 CM on DNA synthesis with the NRK cells at rest in a monolayer (serum free). There was a reduction of DNA synthesis to $15 \%$ of the resting serum-free level after $24 \mathrm{~h}$ of exposure to Hodgkin's TGF. The data are presented in Table I.

\section{Biochemical characterization}

Hodgkin's TGF was secreted from the L-428 cells in a fully active form. Essentially all manipulations reduced the activity except repeated freeze-thawing and mild heating $\left(60^{\circ} \mathrm{C} \times 30\right.$ $\mathrm{min})$. No manipulation enhanced the activity. Boiling reduced the activity $98 \%$ and trypsinization destroyed the Hodgkin's TGF completely (see Table II).

(a) pH sensitivity of Hodgkin's TGF. Because of the reported requirement for acidification to activate TGF- $\beta$ and the use of $1 \mathrm{M}$ acetic acid in the purification schemes for TGF- $\beta$ (9, 11-20, 25), we evaluated the effect of transient and sustained acidification on Hodgkin's TGF activity. An example is demonstrated in Table III. Within 30 min, the activity has been reduced to $2-3 \%$, at which time it becomes stable.

(b) Preservation of Hodgkin's TGF using protease inhibitors. Because Hodgkin's TGF is secreted in an active form at physiologic $\mathrm{pH}$ we hypothesized that endogenous proteases might be cleaving a large molecule and releasing the active TGF- $\beta$ fragment. To test this proposal, we examined both the action of an exogenous protease (trypsin) as well as the inhibition of endogenous proteases to determine the role of proteases in the activation of Hodgkin's TGF. We found that proteases are not responsible for the activation of Hodgkin's TGF and destroy its activity over time (see Tables II and IV).

Table I. Inhibition of Adherence-dependent NRK DNA Synthesis by Hodgkin's TGF

\begin{tabular}{lc}
\hline \multicolumn{1}{c}{ Condition } & Thymidine incorporation \\
& $c p m$ \\
Serum-free medium & $1,899 \pm 117$ \\
$1 \%$ FCS & $2,103 \pm 895$ \\
Hodgkin's TGF & $285 \pm 85$
\end{tabular}

NRK cells were brought into rest by culture in serum-free medium for $24 \mathrm{~h}$ before adding the growth factors to test dishes.
Table II. Effect of Protease and Heat on L-428 TGF

\begin{tabular}{lc}
\hline \multicolumn{1}{c}{ Condition } & Activity* \\
\hline & $\%$ \\
Untreated & 100 \\
Trypsin $(0.25 \%$ for $5 \mathrm{~min})$ & 0 \\
$60^{\circ} \mathrm{C}($ for $30 \mathrm{~min})$ & 100 \\
$100^{\circ} \mathrm{C}($ for $5 \mathrm{~min})$ & 2 \\
\hline
\end{tabular}

* Activity was measured using the NRK colony assay.

(c) PAGE. Hodgkin's TGF submitted to PAGE in physiologic conditions allowed elution of two bands of biological activity from slices at 300 and $350 \mathrm{kD}$ (Fig. $4 \mathrm{~A}$ ) but after exposure to SDS (1\%) the high molecular weight bands were no longer visible even with silver staining. A prominent band at 25,000 D was noted that was comparable to an identical band of TGF- $\beta$ obtained from purified platelets (Fig. $5 A$ ). Testing of eluates from slices of the entire SDS-gel indicated that TGF- $\beta$ activity could be found only in the 25,000 -D slice (Fig. $5 B$ ).

(d) Western blotting. Transfer of native and SDS-treated Hodgkin's TGF to nitrocellulose confirmed the cross-reactivity of high molecular weight Hodgkin's TGF with anti-TGF- $\beta$ antibody. After dissociation in SDS, a 25,000-D molecule was present, which electrophoresed in parallel with TGF- $\beta 1$ from platelets. This 25,000 -D molecule also cross-reacted with antiTGF- $\beta$ (Fig. 4 B).

(e) Ion exchange chromatography. Ion exchange demonstrated binding of Hodgkin's TGF to DEAE-agarose and not to CM-agarose, indicating that the Hodgkin's TGF is a weak acid at physiologic $\mathrm{pH}$. The peak Hodgkin's TGF activity was eluted at $20 \mathrm{mS}$ of electroconductivity.

\section{Discussion}

The biological activity of Hodgkin's TGF has been previously reported in the serum-free CM of short-term cultures of partially purified Reed-Sternberg and mononuclear Hodgkin's cells from nodular sclerosis $(3,4)$. We studied the L-428 Hodgkin's cell line to determine if L-428 cells produced similar biological activity and to characterize the nature of this TGF.

We report here that L-428 cells express mRNA for TGF- $\beta$ and secrete large amounts of a potent growth factor for fibro-

Table III. Acidification of L-428 Hodgkin's TGF

\begin{tabular}{lcc}
\hline \multicolumn{1}{c}{ Condition } & \multicolumn{2}{c}{ Activity } \\
\hline & $p M^{*}$ & $\%$ \\
Untreated & 1,800 & 100 \\
Time of incubation in 1 M acetic acid & & \\
$15 \mathrm{~min}$ & 100 & 5.6 \\
$30 \mathrm{~min}$ & 40 & 2.2 \\
$60 \mathrm{~min}$ & 50 & 2.8 \\
$120 \mathrm{~min}$ & 54 & 3 \\
\hline
\end{tabular}

* AKR-2B bioassay for TGF- $\beta$. 
Table IV. Inhibition of Endogenous Proteases Protects Hodgkin's TGF

\begin{tabular}{crr}
\hline Condition & \multicolumn{2}{c}{ Activity } \\
\hline & $p M$ & $\%$ \\
Time until proteases were inhibited & & \\
$1 \mathrm{~h}$ & 20 & 100 \\
$6 \mathrm{~h}$ & 17 & 85 \\
$24 \mathrm{~h}$ & 13 & 65 \\
No inhibitors (measured at $48 \mathrm{~h}$ ) & 4 & 20 \\
\hline
\end{tabular}

* $53 \mathrm{mg} /$ liter PMSF and $3 \mathrm{mg} /$ liter pepstatin A.

blasts. This growth factor is bifunctional because it induces the growth of human diploid and embryonic fibroblasts but, under identical conditions, inhibits NRK fibroblasts and bronchial epithelial cells in monolayer. However, these same NRK fibroblasts form colonies in soft agar when stimulated by Hodgkin's TGF. These results are identical to the bifunctional activity reported for TGF- $\beta(17,18,25)$.

Additional evidence that Hodgkin's TGF contains the TGF- $\beta$ molecule comes from our observation that AKR-2B cells, which form few or no colonies in response to highly purified EGF or TGF- $\alpha(12,13)$, form colonies in response to either Hodgkin's TGF or TGF- $\beta$.

To further compare Hodgkin's TGF with TGF- $\beta$, we measured the binding of Hodgkin's TGF to the saturable, high-affinity TGF- $\beta$ receptors of the AKR-2B cells and demonstrated specific binding by Hodgkin's TGF to this receptor, as measured by competition for the receptor with ${ }^{125} \mathrm{I}-\mathrm{TGF}-\beta$. We

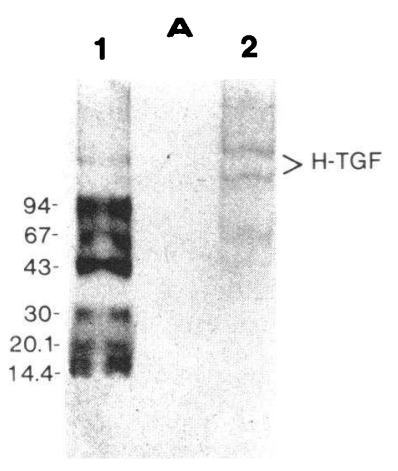

Figure 4. (A) Hodgkin's TGF was prepared using sizing chromatography and DEAE-agarose ion exchange. Gel electrophoresis at physiologic $\mathrm{pH}$ yielded two bands. Identical unstained gels sliced horizontally demonstrated TGF- $\beta$ activity in the slices corresponding to the two stained bands $(\sim 300$ and $350 \mathrm{kD})$.

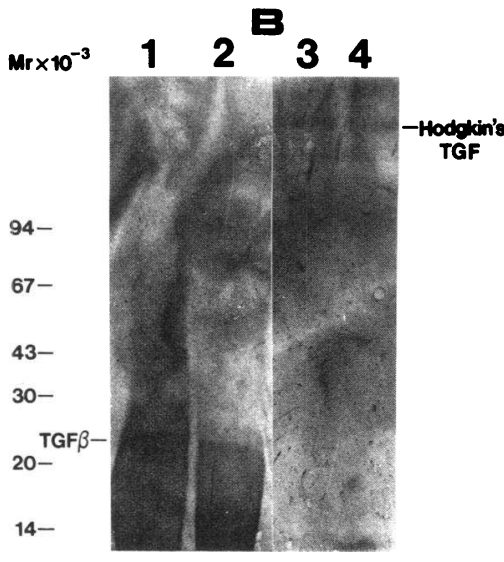

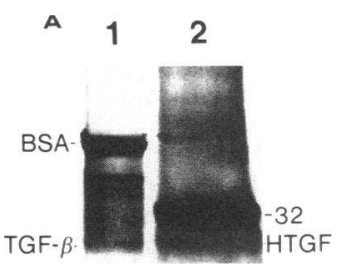

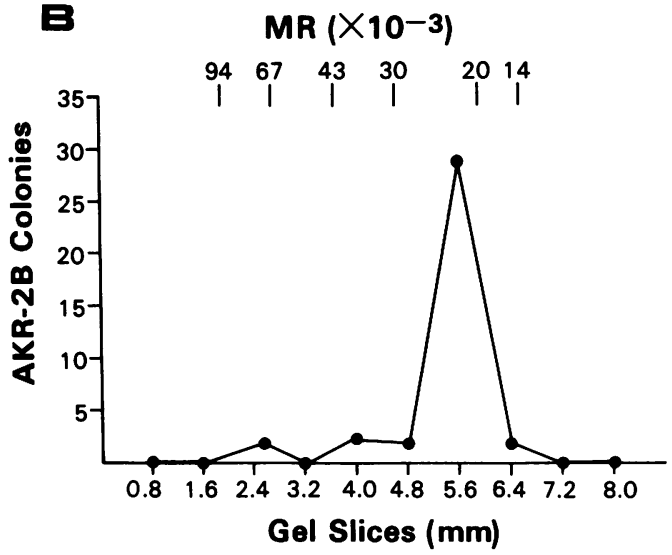

Figure 5. (A) SDS-PAGE of purified Hodgkin's TGF demonstrating 25,000-D Hodgkin's TGF (lane 2) corresponding to a similar band (lane 1 ) containing TGF- $\beta$ purified from platelet alpha granules $(B)$ 8-mm gel slices from SDS-PAGE of Hodgkin's TGF were electroeluted and the eluates were tested for AKR-2B colony forming activity. Activity corresponds to the 25,000-D slice.

have also shown that Hodgkin's TGF does not compete for the TGF- $\alpha$ (EGF) receptors on the membrane of human diploid fibroblasts.

In contrast to the ubiquitous 25,000 -D TGF- $\beta$ extracted by acid-ethanol from many sources $(9,11-20,25)$, we found that the Hodgkin's TGF is secreted as a potent active form at physiologic $\mathrm{pH}$ and is almost, but not completely, destroyed by acidification (97\%). In addition, there was no evidence that Hodgkin's TGF requires activation by proteases. Hodgkin's TGF is destroyed by exposure to an exogenous protease (tryp$\mathrm{sin}$ ) and is protected by inhibition of endogenous proteases. (A comparison of the properties of Hodgkin's TGF and TGF- $\beta$ is presented in Table V.)

Partial purification of Hodgkin's TGF supports the concept that Hodgkin's TGF contains the TGF- $\beta$ molecule, not only because of specific receptor binding, but because a prominent $25,000-\mathrm{D}$ band, identical to purified TGF- $\beta$, appeared after exposure of Hodgkin's TGF to SDS. This band crossreacted with anti-TGF- $\beta$ antibody and was eluted from the gel and shown to have TGF- $\beta$ biological activity.

The physiologic role of TGF- $\beta$ is unclear. Although extensive work has been performed and many in vitro (11-20,25) and some in vivo experiments $(26,27)$ indicate the possibility of important functions of TGF- $\beta$, the observation that a $\mathrm{pH}$ of 2 or less is required to obtain an active growth factor makes it unlikely that TGF- $\beta$ (25,000-D form) is important in physiologic cellular interactions. The purified material $(25,000 \mathrm{D})$ has been demonstrated to have activity for most cells (usually inhibitory) and most cells appear to have specific high affinity receptors for the TGF- $\beta$ molecule (28-30). These same recep- 
Table V. Comparison of Hodgkin's TGF and TGF- $\beta$

\begin{tabular}{|c|c|c|}
\hline Feature & Hodgkin's TGF & TGF- $\beta$ \\
\hline Physiologic pH & Most active & Requires acidification \\
\hline Acidification & Reduces activity $97 \%$ & Activates growth factor \\
\hline Biological actions & Bifunctional & Bifunctional \\
\hline Receptor & TGF- $\beta$ & TGF- $\beta$ \\
\hline $\begin{array}{l}\text { Native molecular } \\
\text { weight }\end{array}$ & $350 \mathrm{kD}$ & $25 \mathrm{kD}$ \\
\hline $\begin{array}{l}\text { SDS molecular } \\
\text { weight }\end{array}$ & $25 \mathrm{kD}$ & $25 \mathrm{kD}$ \\
\hline Anti-TGF- $\beta$ & Cross-reacts & Cross-reacts \\
\hline $\begin{array}{l}\text { Competition for } \\
\text { EGF receptor }\end{array}$ & None & None \\
\hline Ion exchange & DEAE- (acidic) & CM- (basic) \\
\hline Effect of proteases & Destroys activity & Destroys activity \\
\hline Effect of boiling & Reduces activity $98 \%$ & Stable \\
\hline
\end{tabular}

tors also bind the high molecular weight Hodgkin's TGF. It has been proposed that acidification of an inactive pro-TGF- $\beta$ may take place in the lysosome in vivo, but proof of this proposal is lacking and the sensitivity of TGF- $\beta$ to some proteases makes the proposal difficult to defend.

We propose that nodular sclerosing Hodgkin's disease is an example of a malignancy in which neoplastic cells continuously secrete a previously undescribed form of TGF- $\beta$ that is active at physiologic $\mathrm{pH}$ and destroyed by proteases. Others have reported that the MCF-7 breast cancer cell line (31) and certain rat liver tumor cells (32) produce TGF- $\beta$ active at physiologic $\mathrm{pH}$, although these growth factors have not been further characterized. Hodgkin's TGF may consist of TGF- $\beta$ molecules transported as a complex (molecular weight $\cong 350$ $\mathrm{kD}$ ) made up of four or five TGF- $\beta$ molecules or the complex may contain a carrier substance which potentiates the action of TGF- $\beta$ stoichiometrically. Acidification and boiling destroy the complex or important carrier, leaving a less potent acidstable 25,000 -D growth factor that has been characterized as TGF- $\beta$.

Although speculative, it appears likely to us that in benign inflammatory reactions and wound healing, fibroblast proliferation is partially mediated by a molecular form of TGF- $\beta$ similar to Hodgkin's TGF rather than the acid-stable low molecular weight form characterized to date $(9,11-20,25,26)$. The secretion of a physiologically active high molecular weight form of TGF- $\beta$ might be a transient feature of nonmalignant cells that may account for the failure to identify the complete growth factor previously.

\section{Acknowledgments}

We wish to thank Lisa H. Muth for excellent technical assistance and Dr. Keith D. Wilkinson, Department of Biochemistry, Emory University for helpful advice.

This work was supported by CA-30565, CA-39934, and RR-M0101032 from the National Institutes of Health, Bethesda, MD; and CH 254A from the American Cancer Society, Atlanta, GA.

\section{References}

1. Lukes, R. J., and J. J. Butler. 1966. The pathology and nomenclature of Hodgkin's disease. Cancer Res. 26:1063-1081.
2. Kaplan, H. S. 1980 . Hodgkin's Disease. Harvard University Press, Cambridge, MA. 85-95.

3. Newcom, S. R., and L. O'Rourke. 1982. Potentiation of fibroblast growth by nodular sclerosing Hodgkin's cell cultures. Blood. 60:228-237.

4. Newcom, S. R. 1985. The Hodgkin's cell in nodular sclerosis does not release Interleukin-1. J. Lab. Clin. Med. 105:170-177.

5. Schaadt, M. V. Diehl, H. Stein, C. Fonatsch, and H. H. Kirchner. 1980. Two neoplastic cell lines with unique features from Hodgkin's disease. Int. J. Cancer. 26:723-731.

6. Diehl, V., H. H. Kirchner, H. Burichter, H. Stein, C. Fonatsch, J. Gerdes, M. Schaadt, W. Helt, B. Ziegler, A. Ziegler, F. Heintz, and K. Sueno. 1982. Characteristics of Hodgkin's disease derived cell lines. Cancer Treat. Rep. 66:615-632.

7. Falk, M. H., H. Tesch, H. Stein, V. Diehl, D. B. Jones, C. Fonatsch, and G. W. Bornkamm. 1987. Phenotype versus immunoglobulin and T-cell receptor genotype of Hodgkin-derived cells lines:activation of immature lymphoid cells in Hodgkin's disease. Int. J. Cancer. 40:262-269.

8. Sundeen, J., E. Lipford, M. Uppenkamp, E. Sussman, L. Wahl, M. Raffeld, and J. Cossman. 1987. Rearranged antigen receptor genes in Hodgkin's disease. Blood. 70:96-103.

9. Lucas, R. C. 1985. Transforming growth factor, beta. Technical bulletin. R\&D Systems, Inc., Minneapolis, MN.

10. DeLarco, J. E., and G. J. Todaro. 1978. Growth factors from murine sarcoma virus-transformed cells. Proc. Natl. Acad. Sci. USA. 75:4001-4005.

11. Roberts, A. B., L. C. Lamb, D. L. Newton, M. B. Sporn, J. E. DeLarco, and G. E. Todaro. 1980. Transforming growth factors: isolation of polypeptides from virally and chemically transformed cells by acid-ethanol extraction. Proc. Natl. Acad. Sci. USA. 77:3494-3498.

12. Moses, H. L., E. L. Branum, L. A. Proper, and R. A. Robinson. 1981. Transforming growth factor production by chemically transformed cells. Cancer Res. 41:2842-2848.

13. Childs, C. B., J. A. Proper, R. F. Tucker, and H. L. Moses. 1982. Serum contains a platelet-derived transforming growth factor. Proc. Natl. Acad. Sci. USA. 79:5312-5316.

14. Roberts, A. B., C. A. Frolik, M. A. Anzano, and M. B. Sporn. 1983. Transforming growth factors from neoplastic and nonneoplastic tissues. Fed. Proc. 42:2621-2625.

15. Assoian, R. K., A. Komoriya, C. A. Meyers, and M. B. Sporn. 1983. Transforming growth factor-beta in human platelets: identification of a major storage site, purification, and characterization. J. Biol. Chem. 259:7155-7160.

16. Frolik, C. A., L. L. Dar, C. A. Meyers, D. M. Smith, and M. B. Sporn. 1983. Purification and initial characterization of a type beta transforming growth factor from human placenta. Proc. Natl. Acad. Sci. USA. 80:3676-3680.

17. Roberts, A., M. Anzano, C. Meyers, J. Wideman, R. Blacher, Y. E. Ran, S. Stein, S. R. Lehrman, J. M. Smith, L. C. Lamb, and M. B. Sporn. 1983. Purification and properties of a type beta transforming growth factor from bovine kidney. Biochemistry. 22:5692-5698.

18. Tucker, R. F., G. D. Shipley, H. L. Moses, and R. W. Holley. 1984. Growth inhibitor from BSC-1 cells closely related to platelet type beta-transforming growth factor. Science (Wash. DC). 226:705-707.

19. Carr, B. I., I. Hayask, E. L. Branum, and H. L. Moses. 1986. Inhibition of DNA synthesis in rat hepatocytes by platelet-derived type beta-transforming growth factor. Cancer Res. 46:2330-2334.

20. Sporn, M. B., A. B. Roberts, L. M. Wakefield, and R. K. Assoian. 1986. Transforming growth factor-beta: biological function and chemical structure. Science (Wash. DC). 233:532-534.

21. Kadin, M., K. Nasu, D. Sako, J. Said, and E. Vonderheid. 1985. Lymphomatoid papulosis: a cutaneous proliferation of activated helper T cells expressing Hodgkin's disease-associated antigens. Am. J. Pathol. 119:315-325.

22. Muramoto, L. M., and M. E. Kadin. 1987. Improved detection of lymphoid cell surface antigens in tissues fixed in periodate-lysine paraformaldehyde (PLP). Am. J. Clin. Pathol. 88:589-595. 
23. Laemmli, U. K. 1970. Cleavage of structural proteins during the assembly of the head of bacteriophage T4. Nature (Lond.). 227:680-685.

24. Derynck, R., J. A. Jarret, E. Y. Chen, D. H. Eaton, J. R. Bell, R. K. Assoian, A. B. Roberts, M. B. Sporn, and D. V. Goeddel. 1985. Human transforming growth factor-beta complementary DNA sequence and expression in normal and transformed cells. Nature (Lond.). 316:701-705.

25. Roberts, A. B., M. A. Anzano, L. M. Wakefield, N. S. Roche, D. F. Stern, and M. B. Sporn. 1985. Type beta-transforming growth factor: a bifunctional regulator of cellular growth. Proc. Natl. Acad. Sci. USA. 82:119-123.

26. Roberts, A. B., M. B. Sporn, R. K. Assoian, J. M. Smith, N. S. Roche, L. M. Wakefield, U. I. Heine, L. A. Liotta, V. Falang, J. H. Kehrl, and A. S. Fauci. 1986. Transforming growth factor type beta:rapid induction of fibrosis and angiogenesis in vivo and stimulation of collagen formation in vitro. Proc. Natl. Acad. Sci. USA. 83:4167-4171.

27. Mustoe, T. A., G. F. Pierce, A. Thomason, P. Gramates, M. B. Sporn, T. F. Deuel. 1987. Accelerated healing of incisional wounds in rats induced by transforming growth factor-beta. Science (Wash. DC). 237:1333-1336.

28. Tucker, R. F., E. L. Branum, G. D. Shipley, R. J. Ryan, and H. L. Moses. 1984. Specific binding to cultured cells of ${ }^{125}$ I-labeled transforming growth factor type-beta from human platelets. Proc. Natl. Acad. Sci. USA. 81:6757-6761.

29. Frolik, C. A., L. M. Wakefield, D. M. Smith, and M. B. Sporn. 1984. Characterization of a membrane receptor for transforming growth factor-beta in normal rat kidney fibroblasts. J. Biol. Chem. 259:10995-11000.

30. Massague, J., and B. Like. 1985. Cellular receptors for type beta transforming growth factor. J. Biol. Chem. 260:2636-2645.

31. Knabbe, C., M. E. Lippman, L. M. Wakefield, K. C. Flanders, A. Kasid, R. Derynck, and R. B. Dickson. 1987. Evidence that transforming growth factor-beta is a hormonally regulated negative growth factor for human breast cancer cells. Cell. 48:417-428.

32. Liu, C., M.-S. Tsao, and J. W. Grisham. 1988. Transforming growth factors produced by normal and neoplastically transformed rat liver epithelial cells in culture. Cancer Res. 48:850-855. 